Louisiana State University

LSU Digital Commons

Faculty Publications

Department of Oceanography \& Coastal

Sciences

$10-31-2008$

Restoration Of Dredged Canals In Wetlands: A Comparison Of

Methods

Joseph Baustian

Louisiana State University and Agricultural and Mechanical College, baustian@lsu.edu

R. Eugene Turner

euturne@lsu.edu

Nancy F. Walters

David P. Muth

Follow this and additional works at: https://digitalcommons.Isu.edu/oceanography_coastal_pubs

Digitadrt of the Oceanography Commons

Commons

Network

Recommended Citation

Baustian, J., Turner, R., Walters, N. F., \& Muth, D. P. (2008). Restoration Of Dredged Canals In Wetlands: A

Comparison Of Methods. https://doi.org/10.1007/s11273-008-9122-6

This Article is brought to you for free and open access by the Department of Oceanography \& Coastal Sciences at LSU Digital Commons. It has been accepted for inclusion in Faculty Publications by an authorized administrator of LSU Digital Commons. For more information, please contact ir@lsu.edu. 


\title{
Restoration of dredged canals in wetlands: a comparison of methods
}

\author{
Joseph J. Baustian · R. Eugene Turner · \\ Nancy F. Walters · David P. Muth
}

Received: 26 February 2007 / Accepted: 16 October 2008/Published online: 31 October 2008

(C) Springer Science+Business Media B.V. 2008

\begin{abstract}
A comparison of two methods for restoring dredged canals to wetlands was examined at the Jean Lafitte National Historical Park and Preserve's Barataria Preserve Unit near New Orleans, LA. Both northern and southern canals had the remnant dredged spoil material returned to the canal, but the southern canal had additional sediment pumped in from a nearby lake. The water depth in the southern canal shallowed significantly from 1.2 to $0.4 \mathrm{~m}$ following backfilling and sediment addition, while the depth of the northern canal (which received no additional sediment) remained unchanged following backfilling. Neither site had complete soil restoration, but the former spoil areas of the northern canal showed greater restoration than the southern canal. The vegetation on the former spoil areas of the northern canal closely resembled that of the reference marsh, while the former spoil areas of the southern canal had species indicative of spoil banks and other elevated areas. After 3 years wetland vegetation was established on approximately $65 \%$ of the former spoil areas at both sites and $20-25 \%$ of the open water
\end{abstract}

J. J. Baustian $(\bowtie) \cdot$ R. E. Turner

Department of Oceanography and Coastal Sciences, Louisiana State University, Baton Rouge, LA 70803, USA e-mail: baustian@1su.edu

N. F. Walters · D. P. Muth

Jean Lafitte National Historical Park and Preserve, 419 Decatur Street, New Orleans, LA 70130-1035, USA areas. Sediment addition to the southern canal raised costs by a factor of eight times compared to that of the northern canal. The results of this study document the restoration potential of both methods, but also show that backfilling without supplemental sediment additions can restore abandoned canals at a fraction of the cost of other methods.

Keywords Backfilling · Canals · Cost · Dredging · Louisiana . Wetland restoration

\section{Introduction}

A viable technique to restore dredged canals to their former coastal wetland habitat is to return the dredged materials into the channel from which they were removed (Neill and Turner 1987; Turner et al. 1994; Baustian and Turner 2006). This process, called "backfilling" is an appropriate technique to use in Louisiana, a state that has lost 3.95 thousand $\mathrm{km}^{2}$ of coastal land to open water since the 1930s and which has thousands of kilometers of dredged canals and spoil banks (Baumann and Turner 1990; Morton et al. 2005; Turner and Streever 2002). The dredging of canals has contributed directly to land loss in Louisiana by conversion of wetland habitat to open water, and additional wetland area is lost from the indirect impacts (Turner 1987, 1997). Canal restoration via backfilling accomplishes two 
things: it brings the former spoil bank to marsh elevation and partially re-fills the canal. These two developments can lead to the colonization of the former spoil bank by marsh vegetation, create shallow water habitat, and remove the hydrological impediment imposed by the spoil bank. A recent evaluation of canals backfilled more than 20 years ago demonstrated that the success of backfilling depends, to a considerable degree, on dredge operator skill (Baustian and Turner 2006).

Backfilling is not a widely applied restoration technique, in part because of the uncertainties about the costs, and also because open water remains after backfilling. It is possible that backfilling would be more appealing if the canal could be quickly filled. One way to accomplish this is to bring additional sediment from off-site to supplement the material returned to the canal from the spoil banks. The costs of these supplemental materials, however, would be an important consideration where financial efficacy is a factor in choosing among alternative restoration methods. The cost of several small scale restoration alternatives for this coast are estimated to range from $\$ 1$ to $\$ 44,600 \mathrm{ha}^{-1}$ (Turner and Streever 2002), and the average for 63 large projects in the first 5 years of The Coastal Wetlands Planning, Protection and Restoration Act (a State-Federal coastal restoration program) had an anticipated net gain of 479 ha years ${ }^{-1}$ at a funded average cost of $\$ 28,600 \mathrm{ha}^{-1}$ (Louisiana Department of Natural Resources 1995). Documenting the actual costs of backfilling from constructed, rather than planned projects, has been problematic because few canals are being backfilled and these backfilled canal restoration projects are usually the result of private legal agreements.

Here we report on the costs and success of using, or not using, supplemental materials to backfill two dredged canals in south Louisiana. One canal was backfilled by dragging the spoil bank remnants back into the dredged channel, and a second canal was backfilled in the same fashion, but with supplemental fill material added following spoil bank removal. Evaluations of restoration success were based on the re-establishment of marsh vegetation on the former spoil areas and in the canal, as well as restoration of the soils of the former spoil bank. We report on the comparative success of backfilling after 5 years and the costs for various parts of the project. This study provides new insights into the restoration process because monitoring began before the canals were backfilled and changes were continuously documented.

\section{Materials and methods}

Description of the study area

The study site was in the 8,097 ha Barataria Preserve Unit (the Preserve) of Jean Lafitte National Historical Park and Preserve. The preserve, located in the upper Barataria basin, includes a diverse array of habitat types including natural levee crest and backslope bottomland hardwood forest, baldcypress swamp, and fresh and intermediate marsh. These habitat types are typically found on a cross-section of an abandoned distributary lobe of the Mississippi river (O'Neil 1949). The preserve's estuarine marshes are composed of floating or quaking organic soils. National Park Service (NPS) management policies mandate that natural biological and physical processes altered by humans should be restored to natural, or near natural, conditions within National Parks (NPS 2000). Restoration of the canals at the preserve dredged for oil exploration is consistent with this goal.

The two backfilled canals we studied are located about $30 \mathrm{~km}$ south of the city of New Orleans, LA, on the west side of the Mississippi river (Fig. 1).

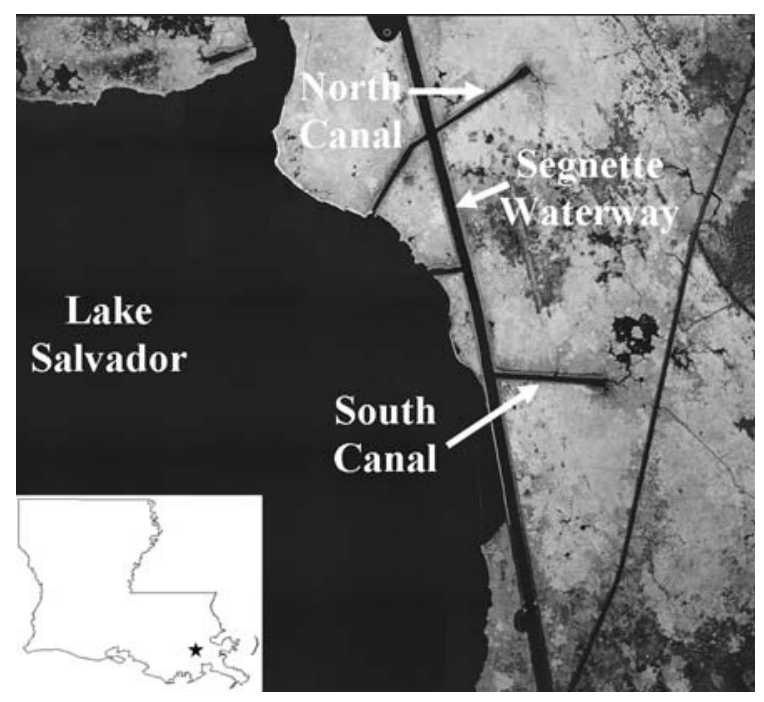

Fig. 1 The location of the two canals backfilled at Jean Lafitte National Historical Park and Preserve 
Table 1 Canal dimensions in 1998 prior to backfilling

\begin{tabular}{llllllll}
\hline & $\begin{array}{l}\text { Canal depth } \\
(\mathrm{m})\end{array}$ & $\begin{array}{l}\text { Canal length } \\
(\mathrm{m})\end{array}$ & $\begin{array}{l}\text { Canal width } \\
(\mathrm{m})\end{array}$ & $\begin{array}{l}\text { Canal area } \\
(\text { ha) }\end{array}$ & $\begin{array}{l}\text { Spoil width } \\
(\mathrm{m})\end{array}$ & $\begin{array}{l}\text { Spoil } \\
\text { area (ha) }\end{array}$ & $\begin{array}{l}\text { Total impact } \\
\text { area (ha) }\end{array}$ \\
\hline Northern canal & 1.1 & 960 & 47 & 4.5 & 14 & 2.7 & 7.2 \\
Southern canal & 1.2 & 914 & 54 & 4.9 & 19 & 3.5 & 8.4 \\
\hline
\end{tabular}

The northern canal was originally dredged into the marsh from the eastern shore of Lake Salvador in 1954 to bring in equipment to drill an oil well. The southern canal was dredged in 1958 off of the newly constructed Segnette Waterway for the same purpose. The canals were similar in shape and size when they were dredged, and 40 years later the canals dimensions remained similar to each other (Table 1).

Backfilling at the northern canal began 12 December 2001 using an all terrain vehicle (locally called a marsh buggy) to return the spoil banks and the trees growing on the spoil banks to the open water portion of the canal. Work at the northern canal was completed by 11 January 2002. Backfilling began on the southern canal on 14 January 2002, and was completed by 13 February 2002. Both canals had double earthen plugs installed spanning the gap in the Segnette Waterway spoil banks at the end of the canal. The plugs were built with in-situ dredged material. One plug was on the marsh edge of the Segnette spoil bank, and the other on the channel edge, with open water between. These plugs had small openings cut into them on opposite ends to allow for water exchange and the movement of estuarine organisms between the marsh and the Segnette Waterway. After spoil material and vegetation was removed at the southern canal, a hydraulic dredge was used to pump sediments from the bottom of Lake Salvador into the canal until it was filled. The sediment dredging was complete on 15 May 2002. Frequent site visits were made, sometimes daily, to monitor progress.

\section{Sediment analysis}

The sediments of the former spoil banks and the marsh surrounding each canal were sampled in May 2005 at five locations at each canal to a depth of $10 \mathrm{~cm}$ using a $50 \mathrm{~cm}^{3}$ piston corer. Sediment samples were analyzed to determine percent water content, percent organic matter, and bulk density. The water content was measured as the percent of weight lost after drying the sample at $60^{\circ} \mathrm{C}$ until a constant weight was reached, bulk density was determined on a dry weight per volume basis $\left(\mathrm{g} \mathrm{cm}^{-3}\right)$, and organic matter was measured as the percentage of dry sample weight lost after $1 \mathrm{~h}$ of ignition at $550^{\circ} \mathrm{C}$ (Nelson and Sommers 1996). The marsh surrounding the northern canal was used as the reference marsh for all comparisons of restoration, because the marsh surrounding the southern canal may have been impacted by the addition of sediments from Lake Salvador into the canal. The spoil bank soil along the Segnette Waterway was also sampled to provide baseline soil property data for the spoil banks in the area.

\section{Vegetation analysis}

The spoil bank area was classified into one of three categories: spoil vegetation, marsh vegetation, or open water using aerial photographs taken in July 2005 and October 2004, as well as from ground surveys in May 2005. Spoil vegetation was considered any area that contained trees or other shrubby vegetation normally associated with spoil banks (i.e., Salix nigra, Acer rubrum, Sapium sebiferum). Marsh vegetation was considered any emergent wetland vegetation. The vegetation composition of the marsh and former spoil bank areas were surveyed with five $1 \mathrm{~m}^{2}$ plots from each area evenly spaced around the perimeter of the canal. The surrounding marsh was sampled $50 \mathrm{~m}$ away from the outside edge of the former spoil areas, and the former spoil areas were sampled in the middle of the former spoil area.

The canal depths were measured using a surveying rod in three evenly spaced transects across both canals, with five measurements per transect. All depth measurements were averaged to give one estimate of canal depth.

\section{Statistical analysis}

All statistical analyzes were conducted using Statistical Analysis System software (SAS 2003). Soil 
properties of the surrounding marsh and former spoil areas at each canal were analyzed using one-way analysis of variance (ANOVA) with post-hoc Tukey tests. The canal depths before and after backfilling were compared using an ANOVA. Restoration success is defined here as the percent of the values measured at the restored site compared to the value at the reference site.

\section{Results}

The soil properties of the former spoil areas were not equivalent to the reference marsh 3 years after backfilling. The organic matter levels were significantly higher at the reference marsh than the former spoil areas at both canals and the marsh surrounding the southern canal (Fig. 2). The soil water content was also significantly higher at the reference marsh compared to the former spoil areas, but not significantly different than the marsh surrounding the southern canal. The bulk density of the reference marsh was significantly lower than the former spoil areas at both sites, but not significantly different than the marsh surrounding the southern canal. The bulk density, water content, and organic matter levels of the northern canals former spoil areas were in between the levels of the reference marsh and the unfilled-standing spoil bank on the Segnette Waterway. At the southern canal the bulk density and water content levels were between the reference marsh and the spoil bank on the Segnette Waterway, but the organic matter levels were lower than the reference marsh and the Segnette Waterway spoil bank.

The canal depth was not the same at each site, and varied throughout each canal. The southern canal shallowed significantly from $1.2 \mathrm{~m}$ prior to backfilling, to $0.5 \mathrm{~m} 3$ years after backfilling, while the depth of the northern canal remained at $1.1 \mathrm{~m}$ (Fig. 2). The canals tended to be deepest at the turning basin and in the middle of the canal and shallower nearest the plug end and at the edges. The canals were shallower at the end with the plug which leaves the impression that sediment flow out of the canal was constrained by the plug even though the plugs have openings. This backing up of sediments was more pronounced in the southern canal where additional sediment was added.
Fig. 2 The soil properties $(\mathbf{a}-\mathbf{c})$ of the surrounding marsh (Sur. marsh) and the former spoil areas (Fmr. spoil) of the backfilled canals, and the canal depths (d) before backfilling in 1998 and 3 years post backfilling in 2005. The marsh surrounding the northern canal is the reference marsh. The soil properties of a standing unfilled spoil bank on the Segnette Waterway are denoted by the dashed line. Error bars are $\pm 1 \mathrm{SE}$, and bars sharing similar letters are not significantly different
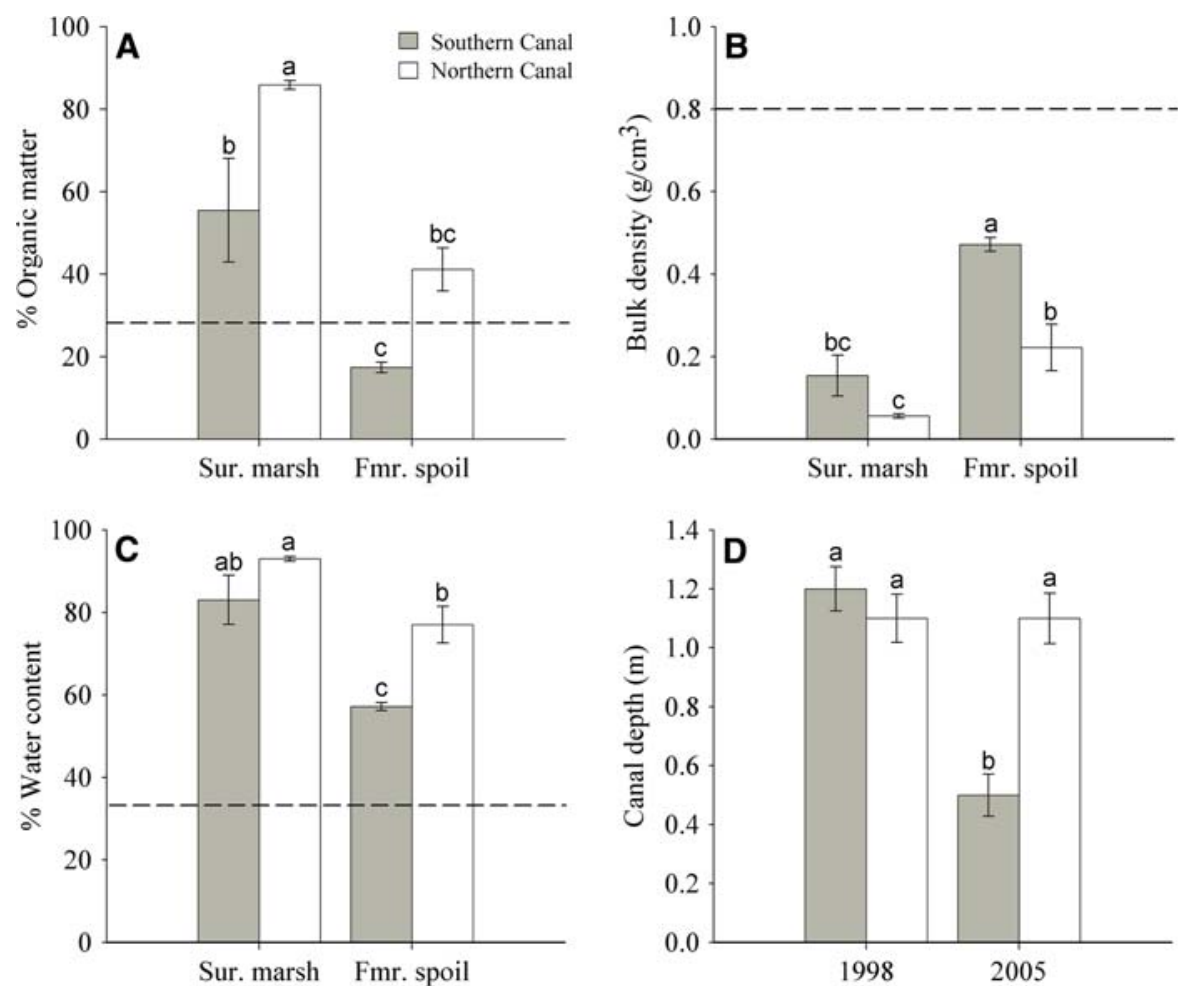
Fig. 3 The northern canal (top) and southern canal (bottom) in 1998 prior to backfilling and 3 years post backfilling in 2005 .

The spoil banks are visible in the 1998 image, and the decrease in width of the open water portions of the canal is evident in the 2005 image
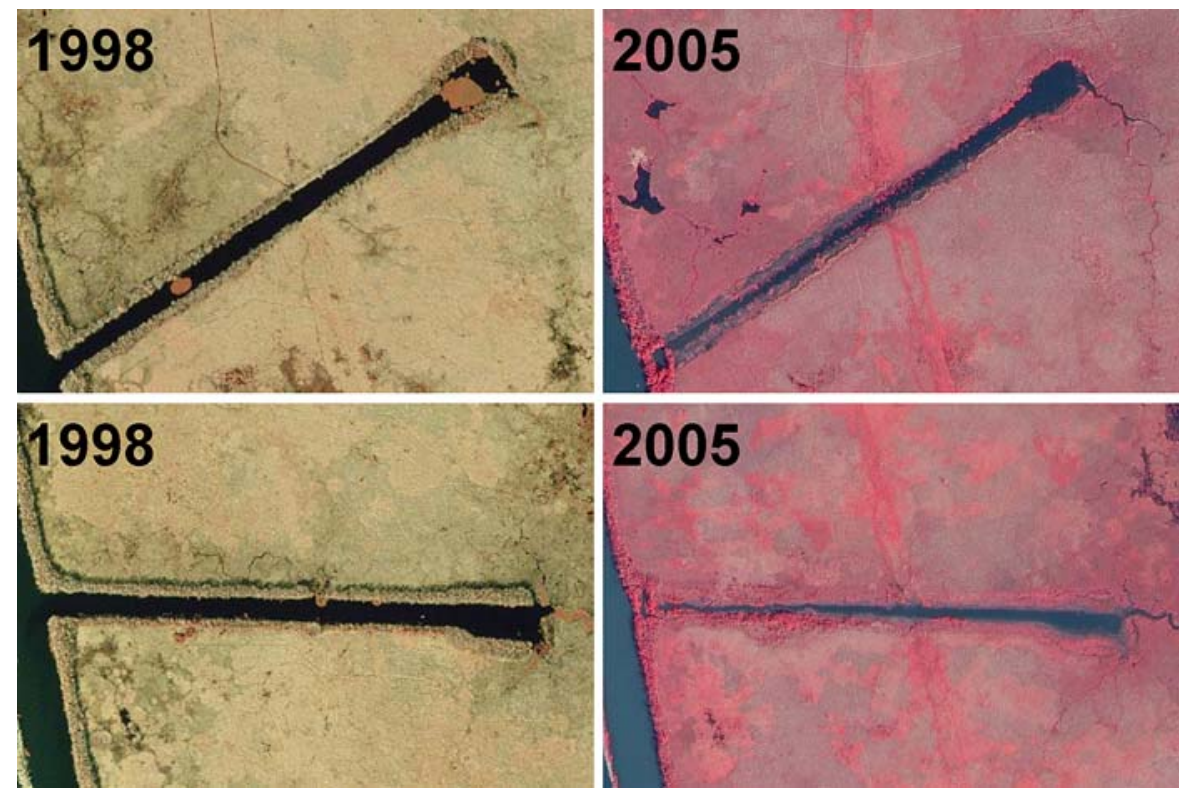

Table 2 Area restored at each canal based on aerial photograph analysis

\begin{tabular}{lllllll}
\hline & $\begin{array}{l}\text { Spoil area as } \\
\text { spoil veg. }(\%)\end{array}$ & $\begin{array}{l}\text { Spoil area as } \\
\text { open water }(\%)\end{array}$ & $\begin{array}{l}\text { Spoil area } \\
\text { restored }(\%)\end{array}$ & $\begin{array}{l}\text { Canal area } \\
\text { restored (\%) }\end{array}$ & $\begin{array}{l}\text { Total area } \\
\text { restored (\%) }\end{array}$ & $\begin{array}{l}\text { Total area } \\
\text { restored (ha) }\end{array}$ \\
\hline Northern canal & 0 & 35 & 65 & 20 & 38 & 2.7 \\
Southern canal & 30 & 5 & 65 & 25 & 42 & 3.5 \\
\hline
\end{tabular}

Backfilling restored marsh vegetation on $65 \%$ of the former spoil areas at both canals after 3 years (Fig. 3; Table 2). The northern canal had the remaining $35 \%$ of its former spoil area converted to shallow open water, while the remainder of the southern canal's former spoil area had become $30 \%$ spoil vegetation and 5\% open water (Table 2). Marsh vegetation was also restored in the open water portions of the canals, $20 \%$ in the northern canal and $25 \%$ in the southern canal (Table 2).

The vegetation in the marsh surrounding both canals was similar, but the species found on the former spoil areas varied between the two sites. The dominant species in the surrounding marsh were Eleocharis sp., Sagittaria lancifolia, and Typha latifolia (Table 3). The former spoil areas of the northern canal were colonized by these same species, although their relative dominance was not the same. The former spoil areas of the southern canal had some of the same dominant species as the surrounding marsh; however, it also had large areas dominated by vegetation not found in the marsh, namely Salix nigra.

\section{Construction costs}

Table 4 includes information on the construction costs for restoring both canals. The total cost for tearing down the spoil banks and building the plugs at both canals and dredging sediment into the southern canal was $\$ 411,200$. The majority of the total project cost ( $\$ 270,398$ plus $\$ 50,000$ mobilization/demobilization) was spent on dredging sediments in Lake Salvador and transporting them into the southern canal. The return of spoil banks to the canals cost of total of $\$ 29,500$ with a $\$ 4,200$ mobilization/demobilization cost, and the construction of the plugs cost $\$ 35,000$ plus $\$ 6,000$ mobilization/demobilization. The construction costs of the southern canal were eight times greater than the northern canal (Table 4). These construction costs do not include the costs of design, compliance, testing, construction oversight, or monitoring. 
Table 3 Relative dominance of the vegetation on the former spoil bank and surrounding marsh of two backfilled canals at Jean Lafitte National Historic Park and preserve based on ground surveys

\begin{tabular}{|c|c|c|c|c|}
\hline \multirow[t]{3}{*}{ Species } & \multicolumn{4}{|c|}{ Relative dominance $(\%)$} \\
\hline & \multicolumn{2}{|c|}{ Northern canal } & \multicolumn{2}{|c|}{ Southern canal } \\
\hline & $\begin{array}{l}\text { Surrounding } \\
\text { marsh }\end{array}$ & $\begin{array}{l}\text { Former } \\
\text { spoil areas }\end{array}$ & $\begin{array}{l}\text { Surrounding } \\
\text { marsh }\end{array}$ & $\begin{array}{l}\text { Former } \\
\text { spoil areas }\end{array}$ \\
\hline Eleocharis spp. & 73 & 30 & 23 & \\
\hline Sagittaria lancifolia & 10 & 39 & 37 & 23 \\
\hline Typha latifolia & 2 & 2 & 21 & Trace \\
\hline Alternanthera philoxeroides & 9 & 23 & 6 & 37 \\
\hline Hydrocotly umbellata & 3 & Trace & 4 & \\
\hline Kosteletzkya virginica & Trace & Trace & Trace & \\
\hline Bidens laevis & Trace & & 2 & \\
\hline Ludwigia leptocarpa & Trace & & & Trace \\
\hline Schoenoplectus americanus & & & Trace & \\
\hline Galium tinctorium & & & Trace & \\
\hline Polygonum spp. & & Trace & Trace & \\
\hline Ipomoea sagittata & & & Trace & \\
\hline Sacciolepis striata & & & Trace & 18 \\
\hline Salix nigra & & & & 18 \\
\hline Bacopa monnieri & & & & Trace \\
\hline Schoenoplectus californicus & & Trace & & \\
\hline Sagittaria latifolia & & Trace & & \\
\hline Juncus effusus & & Trace & & \\
\hline Sapium sebiferum & & Trace & & Trace \\
\hline Acer rubrum & & Trace & & \\
\hline Aeschynomene indica & & Trace & & \\
\hline
\end{tabular}

\section{Costs per area restored}

The construction costs of backfilling the northern and southern canals was $\$ 16,815$ and $\$ 104,514 \mathrm{ha}^{-1}$, respectively, as of 2005. If the entire former spoil area and open water portions of the canal are colonized by marsh vegetation, then the costs per hectare will decrease to $\$ 8,945 \mathrm{ha}^{-1}$ for the northern canal and $\$ 98,443 \mathrm{ha}^{-1}$ and southern canals. If no plugs were built and there was $100 \%$ re-vegetation of the former spoil areas and open water portions of the canal, then the costs would be $\$ 3,399-\$ 41,346 \mathrm{ha}^{-1}$ at the northern and southern canals, respectively.

\section{Discussion}

This study is unique because it compares two methods of backfilling: the typical method where only the local spoil material is returned to the canal and a second method where additional fill material is added to the canal. The addition of sediments to the southern canal was intended to promote the establishment of emergent wetland vegetation in the open water area of the canal remaining after the spoil banks were moved into the canal. There was no appreciable difference, however, in the amount of marsh established in the open water portions of the canals. The apparent lack of influence of the sediment addition may be because the majority of the southern canal was still too deep for emergent vegetation to become established after the dredged sediments dewatered, compacted, and spread out over the marsh or through tidal channels to interior ponds. Also, there may not be much disparity in emergent vegetation establishment between canals because there are plant species present at both sites, such as Ludwigia peploides and Alternanthera philoxeroides, which can grow out from the edge of a water body and begin to build a buoyant mat with their roots and rhizomes. There was evidence of this mat building at both canals, but it was more prevalent in the northern 
Table 4 Itemized construction costs

\begin{tabular}{lr}
\hline Item & Cost (in \$) \\
\hline Performance and payment bond & 8,602 \\
Mobilization of marsh excavator & 2,100 \\
Clear \& grub north and south canal & 29,500 \\
Demobilize marsh excavator & 2,100 \\
Mobilize dragline & 3,000 \\
Construct earthen plugs & 35,000 \\
Demobilize dragline & 3,000 \\
Mobilize hydraulic dredge and support & 25,000 \\
$\quad$ equipment & \\
Seed and armor earthen plugs & 7,500 \\
Hydraulic dredging for southern canal & 270,398 \\
Demobilize hydraulic dredge and support & 25,000 \\
$\quad$ equipment & \\
Southern canal cost & 365,799 \\
Northern canal cost & 45,401 \\
Total cost & 411,200 \\
\hline
\end{tabular}

canal which did not receive the dredged sediment. The southern canal was shallower than the northern canal because of the sediment-infilling, and so the effects of sediment additions may simply take more time to be expressed through changes in vegetative cover.

The dredged sediment addition did have a pronounced effect on the vegetation of the former spoil areas. Both canals had $65 \%$ of their former spoil areas re-established as marsh, but the remainder of the southern canal's former spoil area was dominated by vegetation typical of young spoil banks (i.e., Salix nigra), and the remainder of the northern canal's former spoil area was mostly open water. The open water portions of the northern canal's former spoil areas are a result of the spoil bank being removed to a depth below the normal water level, and emergent vegetation has yet to be established in those shallow open water areas. The portions of the former spoil area of the southern canal that are now covered by spoil vegetation could have developed in one of two ways: (1) the spoil bank was not removed to a low enough depth and spoil vegetation re-established, or, (2) the spoil banks were removed to the appropriate depth, but an excess of the dredged sediment addition was deposited in certain locations which ultimately led to a higher elevation. We think that the second scenario is the more likely one based on observations at the time of dredging.

The outflow pipe from the dredge was moved among several locations within the southern canal to evenly fill in the canal during sediment dredging from Lake Salvador. One of the outflow pipe locations was on the recently backfilled spoil bank on the southern side of the canal. While the pipe was in that location the material being dredged from the lake bottom was very dense (Fig. 4) and did not de-water and compact like the sediments deposited at other locations within the canal. This left the area higher than marsh elevation and allowed for the colonization of willow trees and other spoil vegetation. The presence of spoil vegetation effectively prohibited marsh establishment
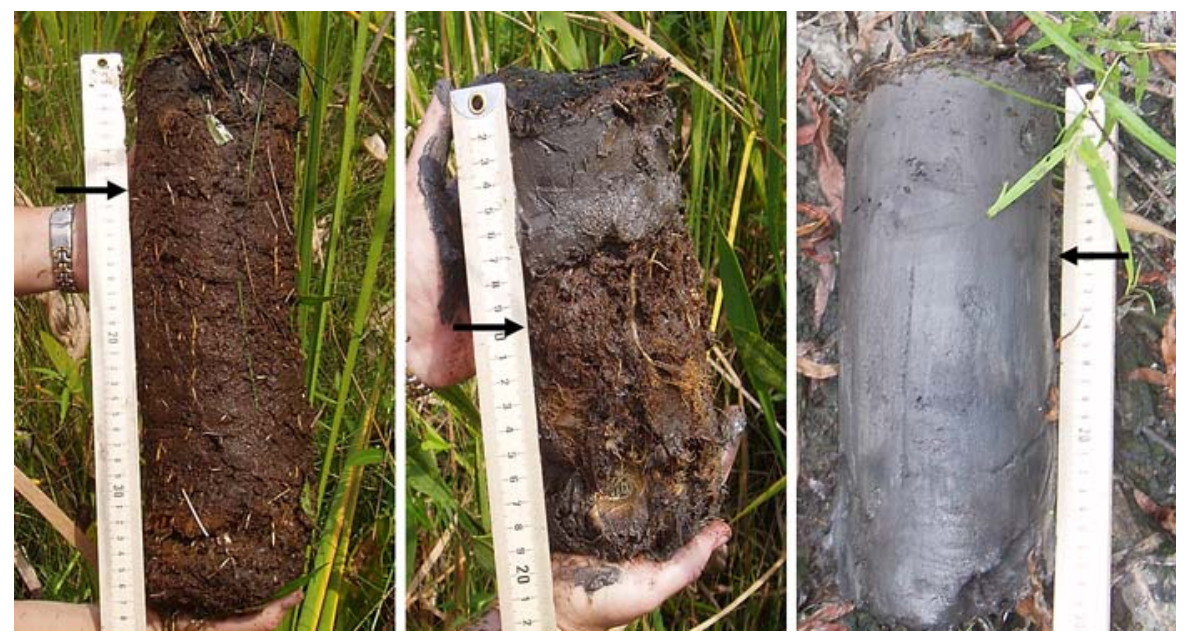

Fig. 4 Cores taken from the reference marsh (left), the marsh surrounding the southern canal (center), and the former spoil area of the southern canal which supports spoil vegetation (right). The arrows point to the $10 \mathrm{~cm}$ mark on each core 
on this section of the former spoil areas at the southern canal, while the open water on the former spoil areas of the northern canal allows for the possibility of future wetland establishment.

The sediment dredged into southern canal was accomplished without using a containment structure, which allowed sediment to leak from the intended open water area disposal area and into the surrounding marsh. This leakage was conspicuous near the plug at the end of the canal where it became a layer of inorganic material, over $10 \mathrm{~cm}$ thick in spots, on top of the pre-existing organic substrate (Fig. 4). The inorganic layer altered the soil structure of the marsh surrounding the southern canal giving it a higher bulk density, lower organic content, and lower water content than the marsh surrounding the northern canal.

The re-colonization success of marsh vegetation on the scraped spoil banks may have been influenced by the elevation at the end of the construction period. During construction it was noted that the operator showed considerable skill in maintaining a fairly even surface. Nevertheless, scraping the spoil bank with a backhoe inevitably results in unevenness and gouging. Furthermore, the operator used visual cues, including fluctuating ambient water levels, to estimate final elevation. It would be possible to use surveying techniques and equipment to maintain more uniformity in final elevation, although doing this would increase costs. Greater control of the amount and final elevation of the material pumped into the southern canal might have resulted in faster re-establishment of emergent vegetation, and better discharge pipe placement would have reduced the amount of sediment deposited on the spoil bank. Traditional marsh creation projects using pumped dredge material utilize strict containment and pumping to some height above desired final elevation to account for compaction and dewatering. Again, using such methods increases the costs.

The NPS did not want to completely close the canal by over-pumping, not only because containment and additional dredge time would have been cost prohibitive, but because doing so would have choked off the tidal connections between the interior marsh and Segnette Waterway. In addition, no data were available to determine the proper ratio of pumped elevation to final elevation, because of the uncertainty about the organic content of the fill material.
Restoration trajectory

The timescale for complete site restoration is presently unknown. Studies on backfilled canals show a maximum $94 \%$ restoration of bulk density and water content and $80 \%$ restoration of organic matter after 20 years (Baustian and Turner 2006). The addition of dredged sediment, which had high bulk density and low organic matter levels, did decrease the depth of the southern canal, but it is also responsible for the former spoil areas of the southern canal being at a relative disadvantage in terms of soil restoration. The portions of the southern canal's former spoil area at a higher elevation also contribute to the lower restoration levels as aerobic respiration in the soil slows the accumulation of organic matter (Stephens et al. 1984).The higher portions of the southern canal's former spoil area, however, may eventually subside to marsh elevation and the processes that build organic marsh soils would, therefore, commence. The open water portions of both canals will likely persist until mat-forming vegetation can successfully build completely across the canals. Thus, the amount of marsh being restored at the sites will depend on how fast emergent vegetation can colonize the open water.

The total cost of this project will not change, although, the cost per hectare restored will continue to decrease as more of the area is restored. The difference between the costs for backfilling with supplemental material, or not, will increase if the original canal depth is deeper than in the case of these canals. The cost of the supplemental material will be higher with additional transport costs, or could be lower if "donated" from maintenance dredging of a navigation channel. The overall costs, and cost per hectare, could be further reduced if no plugs were built. The plugs studied at these sites seemed to hold sediment in the canal, particularly at the southern canal, but previous studies show backfilled canals without plugs become shallower than their plugged counterparts over time (Reed and Rozas 1995; Baustian and Turner 2006).

\section{Conclusions}

Backfilling at the northern canal, involving only dragging the former spoil bank into the canal, effectively began the restoration process; while the 
addition of dredged sediment to the southern canal provided mixed restoration results, and added significantly to the overall project cost. Specifically, the additional sediment led to shallower canal depths, but it also slowed soil restoration and allowed spoil vegetation to re-colonize the former spoil areas. In other aspects, both sites faired equally well in terms of marsh re-establishment on the former spoil areas and in the canal.

Although the restoration process is not complete, these canals have the potential to continue the restoration process and become two excellent examples of canal restoration. The information gathered from these canals can be used as a reference for future restoration projects in the Preserve and throughout Coastal Louisiana.

Acknowledgment We thank the following people who helped in the permit preparation, data collection and monitoring of the project: Kate Carpenter (LSU), James M. Lee (LSU), Erick M. Swenson (LSU), Sandra Dingman, Scott Nesbitt and William J. Hulslander (the Preserve). We would also like to thank the two reviewers for their thoughtful comments on this manuscript. The NPS—Geological Resources Division provided project support and funding.

\section{References}

Baumann RH, Turner RE (1990) Direct impacts of outer continental shelf activities on wetland loss in the central Gulf of Mexico. Environ Geol Water Resour 15:189-198. doi:10.1007/BF01706410

Baustian JJ, Turner RE (2006) Restoration success of backfilling canals in coastal Louisiana marshes. Restor Ecol 14:634-644. doi:10.1111/j.1526-100X.2006.00175.x

Louisiana Department of Natural Resources (1995) Coastal wetlands planning, protection and restoration act: summary of priority lists $1-4$. CWPPRA report series no. 1. Louisiana Department of Natural Resources, Baton Rouge

Morton TA, Bernier JC, Barras JA, Ferina NF (2005) Rapid subsidence and historical wetland loss in the Mississippi delta plain: likely causes and future implications. USGS open-file report 2005-1215

National Park Service (2000) Management policies (2001). Department of the Interior, National Park Service, Washington DC, NPS D1416

Neill C, Turner RE (1987) Backfilling canals to mitigate wetland dredging in Louisiana coastal marshes. Environ Manag 11:823-836. doi:10.1007/BF01867248

Nelson DW, Sommers LE (1996) Total carbon, organic carbon, and organic matter. In: Bartels JM, Bigham JM (eds) Methods of soil analysis. Part 3. Chemical methods. Soil Science Society of America and American Society of Agronomy, Madison, WI, USA, pp 961-1010

O'Neil T (1949) The Muskrat in the Louisiana coastal marshes. Louisiana Department of Wild Life and Fisheries, New Orleans

Reed DJ, Rozas LP (1995) An evaluation of the potential for infilling existing pipeline canals in Louisiana coastal marshes. Estuaries 15:149-158

SAS Institute Inc (2003) The SAS system for Windows, version 9.1. Cary, North Carolina, USA

Stephens JC, Allen LH, Chen E (1984) Organic soil subsidence. In: Holzer T (ed) Geological society of American reviews in engineering geology, vol VI. The Geological Society of America, Boulder, pp 107-122

Turner RE (1987) Relationship between canal and levee density and coastal land loss in Louisiana. U S Fish Wildl Serv Biol Rep 85(14):58

Turner RE (1997) Wetland loss in the northern gulf of Mexico: multiple working hypotheses. Estuaries 20:1-13. doi: $10.2307 / 1352716$

Turner RE, Streever B (2002) Approaches to coastal wetland restoration: northern gulf of Mexico. SPB Academic Publishing, Den Hague

Turner RE, Lee JM, Neill C (1994) Backfilling canals to restore wetlands: empirical results in coastal Louisiana. Wetl Ecol Manag 3:63-78. doi:10.1007/BF00177297 